\title{
BMJ Open Validation of a B-type natriuretic peptide as a prognostic marker in pneumonia patients: a prospective cohort study
}

\author{
Daisuke Usuda, ${ }^{1,2}$ Ryusho Sangen, ${ }^{2}$ Yu Hashimoto, ${ }^{2}$ Emiri Muranaka, ${ }^{2}$ \\ Yoshitsugu linuma, ${ }^{1}$ Tsugiyasu Kanda ${ }^{2}$
}

To cite: Usuda D, Sangen $R$, Hashimoto $Y$, et al. Validation of a B-type natriuretic peptide as a prognostic marker in pneumonia patients: a prospective cohort study. BMJ Open 2016;6:e010440. doi:10.1136/bmjopen-2015010440

- Prepublication history for this paper is available online. To view these files please visit the journal online (http://dx.doi.org/10.1136/ bmjopen-2015-010440).

Received 3 November 2015 Revised 28 December 2015 Accepted 18 January 2016

\section{(a) CrossMark}

${ }^{1}$ Department of Infectious Diseases, Kanazawa Medical University, Uchinada-machi, Ishikawa-ken, Japan ${ }^{2}$ Department of Community Medicine, Kanazawa Medical University Himi Municipal Hospital, Himi-shi, Toyamaken, Japan

Correspondence to Professor Tsugiyasu Kanda; kandat@kanazawa-med.ac.jp

\section{ABSTRACT}

Objectives: To validate a B-type natriuretic peptide (BNP) as a prognostic marker in pneumonia patients. Design: A prospective cohort study.

Setting: Kanazawa Medical University Himi Municipal (a 250-bed community hospital in Himi-shi, Toyamaken, Japan).

Participants: All patients diagnosed with pneumonia by the physician and admitted to our hospital between 1 January 2012 and 31 March 2015 whose BNP levels had been determined in the first $24 \mathrm{~h}$ of admission. A total of 673 patients were enrolled. Of these, BNP levels were measured for a total of 369 patients on admission.

Intervention: After enrolment, baseline, demographic, clinical and laboratory characteristics including levels of suspected prognostic markers for pneumonia proposed in previous papers, were collected. All patients were followed up until discharge. During analysis, they were divided into categories as follows: community-acquired pneumonia (CAP), aspiration pneumonia (AP), healthcare-associated pneumonia (HCAP) and pneumonia with acute heart failure (PAHF). $A$ univariate and multivariable Cox-regression analysis were applied to each parameter to identify predictors of death. Three cut-off points, namely 40, 100 and $200 \mathrm{pg} / \mathrm{mL}$, as well as the mean, were applied when comparing BNP levels.

Main outcome measures: 30-day mortality.

Results: Of the 369 patients finally included, 137 were diagnosed with CAP, 122 with AP, 74 with HCAP, and 36 with PAHF. In the univariate analysis, BNP levels (mean, cut-off points $100 \mathrm{pg} / \mathrm{mL}$ and $200 \mathrm{pg} / \mathrm{mL}$, $p<0.01$, respectively) were associated with death in CAP, and similar situation was found for BNP (cut-off points $200 \mathrm{pg} / \mathrm{mL}, \mathrm{p}<0.05$ ) in AP, but not for HCAP, or PAHF. In multivariable Cox-regression analysis, BNP remained an independent mortality predictor (HR $10.01,95 \% \mathrm{Cl} 1.32$ to $75.7, \mathrm{p}=0.03$ ) in CAP.

Conclusions: BNP levels may be a useful single prognostic marker for CAP. Further research for validation is warranted.

\section{Strengths and limitations of this study}

- To the best of our knowledge, this is the first study to directly compare levels of B-type natriuretic peptide (BNP) with community-acquired pneumonia and aspiration pneumonia, healthcare-associated pneumonia or pneumonia with acute heart failure.

- This is the first study to validate BNP as a prognostic marker in aspiration pneumonia, healthcare-associated pneumonia or pneumonia with acute heart failure, therefore our results build on new findings.

- We should have measured the serum BNP levels in the convalescent phase and the acute phase for evaluation as a decrease in these levels post-treatment, which is compatible with control subjects, would show that BNP levels were transiently elevated in patients with pneumonia.

- We failed to measure BNP for all pneumonia patients, hence a selection bias cannot be completely excluded.

\section{BACKGROUND}

Pneumonia is a major medical problem and is the leading infectious cause of death in developed countries, especially among the elderly. ${ }^{1} 2$ Japan is no exception to this trend. ${ }^{3}$ According to the list of statistical surveys prepared by the Statistics and Information Department at the Japanese Ministry of Health, Labor and Welfare, pneumonia was the third leading causing of death in 2014, with a death toll of $119650 .^{3}$

The pneumonia severity index (PSI), confusion, urea plasma levels, respiratory rate, blood pressure, age over 65 years (CURB-65), and, especially in Japan, the A-DROP scoring system [age (men $\geq 70$ years, women $\geq 75$ years), dehydration (BUN $\geq 21 \mathrm{mg} / \mathrm{dL}$ ), respiratory failure (pulse oximetry $\leq 90 \%$ or $\mathrm{PaO}_{2} \leq 60$ Torr), orientation disturbance, and systolic blood pressure 
$\leq 90 \mathrm{~mm} \mathrm{Hg}$ )] are extensively used and validated tools for estimating the prognosis of patients with community-acquired pneumonia (CAP), although they tend to be difficult to calculate, are prone to individual error, and are partially dependent on individual impressions. ${ }^{4}$ As such, a fast, simple, and reliable predictor is needed for acute situations.

B-type natriuretic peptide (BNP), a 32-amino-acid polypeptide, has consistently been shown to improve the diagnosis and management of unselected patients presenting with acute shortness of breath by reliably separating cardiac from non-cardiac causes of dyspnoea. ${ }^{1}$ This peptide is predominately released by left and right cardiac ventricles and regulates a wide array of physiological effects, including natriuresis, diuresis and vasodilatation. ${ }^{1}$ The main stimulus for secretion of BNP is cardiac stress, as reflected by myocardial stretch and pressure or volume overload. ${ }^{1}$ According to recent research, it has been suggested to be a prognostic factor for CAP. ${ }^{15}$ Despite this, no systematic assessment of BNP levels as a prognostic marker for other types of pneumonia, or studies comparing BNP levels with other markers to validate their effectiveness, has been published to date.

\section{METHODS}

\section{Study design}

We conducted a cohort study in Kanazawa Medical University Himi Municipal Hospital (a 250-bed community hospital in Himi-shi, Toyama-ken, Japan). Verbal and written informed consent was obtained from all participating patients on admission. This study, including the informed consent procedure, was approved by the ethics committee at Kanazawa Medical University Himi Municipal Hospital (approval number 48), and the study was carried out according to the principles of the Declaration of Helsinki.

\section{Data collection}

Before starting this research, we asked all physicians at our hospital to measure BNP levels on admission for all patients who were diagnosed with pneumonia. Data were collected by reviewing electronic medical records held at our hospital, and all patients diagnosed with pneumonia by the physician and admitted to our hospital between 1 January 2012 and 31 March 2015, whose BNP levels had been determined in the first $24 \mathrm{~h}$ of admission, were enrolled.

All patients were subjected to an initial clinical assessment, including medical history, physical examination, ECG, pulse oximetry, blood tests, including arterial blood gas analysis (when indicated), blood culture (when indicated), chest radiograph and chest CT. After enrolment, baseline, demographic, clinical and laboratory characteristics, and outcome data, including levels of suspected prognostic markers for pneumonia proposed in previous papers: $\mathrm{C}$ reactive protein, metabolic acidosis, body temperature, respiratory rate, hypoxaemia, hypercapnia, age, plasma glucose level, serum creatinine level, malignancy, $\mathrm{PaO}_{2} / \mathrm{FiO}_{2}<200$, bacteraemia, were collected. $^{6-13}$ All patients were followed up until discharge.

The inclusion criteria were patients diagnosed as follows: CAP, aspiration pneumonia (AP), healthcare-associated pneumonia (HCAP), pneumonia with acute heart failure (PAHF). The exclusion criteria were patients diagnosed with other types of pneumonia, aged less than 18 years, an obvious traumatic cause of dyspnoea, and patients who requested an early transfer to another hospital. Patients judged not to have been suffering from pneumonia after admission were also excluded.

\section{Measurement of BNP}

BNP was detected in EDTA plasma samples using a fluorescence immunoassay (Biosite Diagnostics, La Jolla, California, USA). The precision, analytic sensitivity, and stability of the system have been described previously. ${ }^{14} 15$ Briefly, the coefficient of variation within a given assay has been reported to be $9.5 \%, 12.0 \%$, and $13.9 \%$ for levels of 28.8, 584.0 , and $1180.0 \mathrm{pg} / \mathrm{mL}$, respectively, while the coefficient of variation between assays is $10.0 \%, 12.4 \%$, and $14.8 \%$, respectively, for the same levels.

\section{Definitions}

Physicians at our hospital diagnosed pneumonia based on signs of a new infiltrate in the chest radiography or chest CT. No single biomarker or pre-specified biomarker level was necessary for diagnosis. Pneumonia was suspected in the presence of three or more of the following recently acquired respiratory signs or symptoms: cough, chest pain, sputum production, dyspnoea, body temperature $>38.0^{\circ} \mathrm{C}$, auscultatory findings of abnormal breath sounds and pulmonary rales, white cell count $>10$ or $<4 \times 10^{9}$ cells $/ \mathrm{L}$, and a new infiltrate in the chest radiography. Each patient was classified into one of the pneumonia categories mentioned above.

Patients were classified in CAP if they did not meet the criteria for AP, HCAP or PAHF.

Although AP is one of the common presentations of CAP and HCAP, its significance has not yet been fully evaluated due to difficulties associated with diagnosis of this condition. ${ }^{16}$ Diagnosis of AP was made based on the Japanese Respiratory Society (JRS) guidelines for the management of hospital-acquired pneumonia, namely overt aspiration (apparent aspiration), a condition in which aspiration was strongly expected, or the existence of abnormal swallowing function or dysphagia. ${ }^{17}$ In addition, water swallowing tests or videoendoscopy were performed to evaluate swallowing function in suspected cases (when indicated).

HCAP was defined according to the JRS guidelines for management of nursing- and HCAP published in August $2011 .^{18}$ HCAP in Japan was defined taking into account the characteristics of the Japanese healthcare system and 
the fact that the 2005 American Thoracic Society and Infectious Diseases Society of America guidelines proposed a new category of pneumonia, namely HCAP. In recent years, changes in medical care environments have led to increasing numbers of CAP patients becoming infected with multidrug-resistant pathogens. As these patients have a poor prognosis when coming into contact with the healthcare system, the concept of HCAP was introduced. HCAP includes patients who meet at least one of the following criteria: (A) residence in a long-term care hospital or a nursing home; (B) discharge from hospital in the past 90 days; $(\mathrm{C})$ elderly or disabled people requiring care (performance status 3 or 4); (D) outpatients who regularly receive infusion therapy (chronic dialysis, antibiotics, cancer chemotherapy or immunosuppressive drugs).

In a previous study, patients with pneumonia together with congestive heart failure had significantly higher serum BNP levels than those with pneumonia alone and the control groups. ${ }^{19}$ The presence or absence of symptoms of congestive heart failure was based on the Framingham scale, ${ }^{20}$ which was based on clinical impression, chest radiograph, and chest CT. Transthoracic echocardiography was included for all patients suspected of congestive heart failure. As such, we tentatively defined a diagnosis of PAHF based on the definition of pneumonia mentioned above together with the Framingham scale.

Patients were classified as HCAP when they met diagnostic criteria for HCAP and AP, and as PAHF when they met the diagnostic criteria for both PAHF and others.

\section{Statistical analysis}

The primary outcome was defined as a 30-day death. Categorical variables are expressed as number and percentage, and continuous variables as mean and SD. When data were missing for a parameter, the number of variables is given in parentheses. The normal distribution of the continuous variables was assessed using the Kolmogorov-Smirnov test. We applied a univariate analysis to compare baseline, demographic, clinical, laboratory characteristics and outcome data between CAP and other pneumonia groups. Three cut-off points, namely 40, 100, and $200 \mathrm{pg} / \mathrm{mL}$, as well as the mean, were applied when comparing BNP levels. To estimate the potential clinical relevance of biomarker measurements, we used logistic regression models. For the comparison between the survival group and non-survival group, the potential confounding variables were entered in the univariate model, and variables that were significant in this model $(\mathrm{p}<0.05)$ were added to a multivariable model. In univariate analysis, Student's t test was used for continuous variables and the $\chi^{2}$ or Fisher exact test for categorical variables. Cox-regression analysis was applied to identify predictors of death in multivariable analysis. Additionally, to assess the potential of the different BNP and risk stratification tools to predict 30-day mortality, receiver operating curve characteristics (ROCs) were compared and cut-off values were calculated by maximising the product of sensitivity and specificity. The statistical analyses were performed using the STATA software package (V.10; STATA Corp LP). A statistical two-tailed significance level of 0.05 was used and all hypothesis testing was also two tailed.

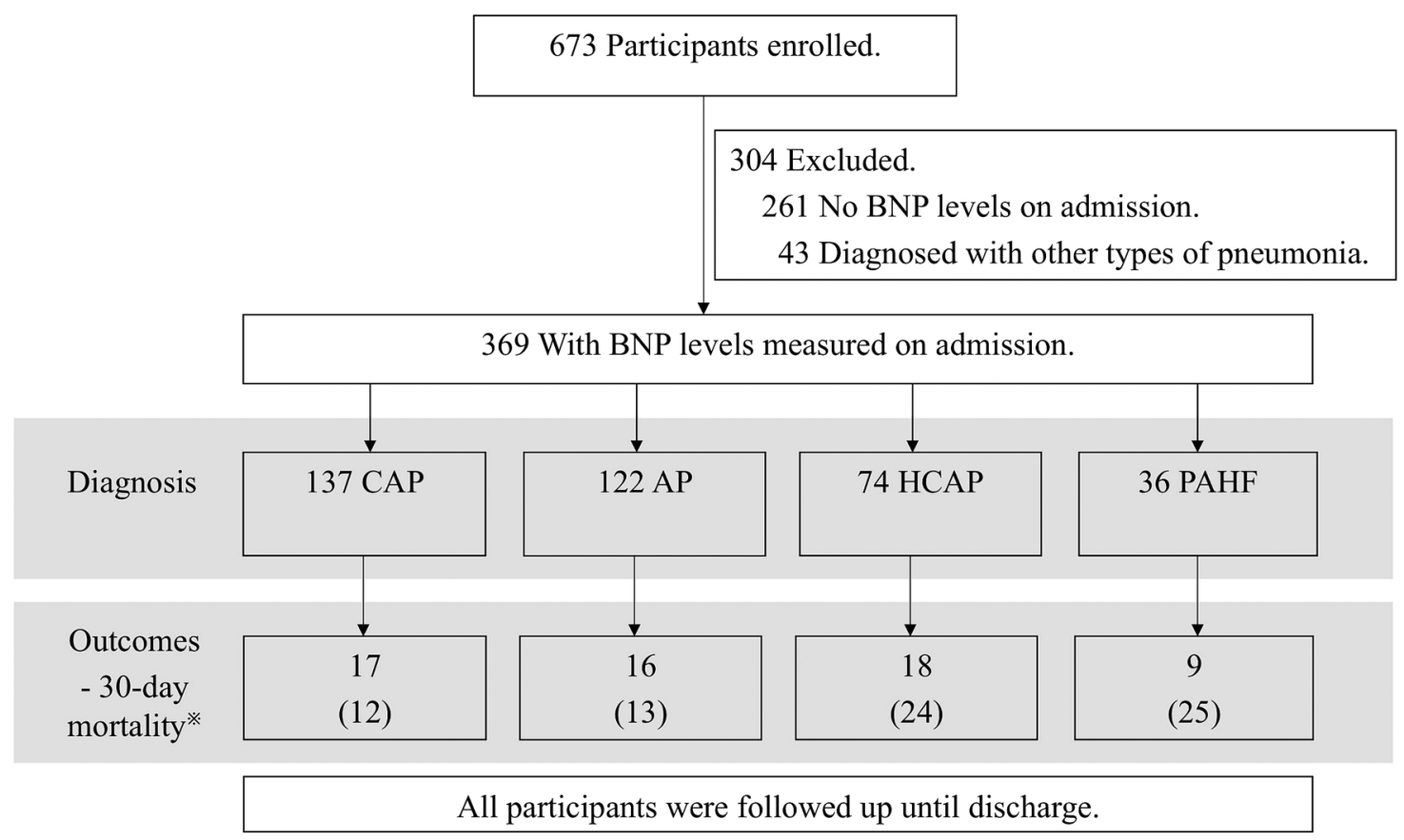

* Data are presented as No. $(\%)$. BNP $=$ B-type natriuretic peptides, $\mathrm{CAP}=\mathrm{Community}-$ Acquired Pneumonia, $\mathrm{AP}=$ Aspiration Pneumonia, HCAP $=$ Healthcare-Associated Pneumonia, PAHF = Pneumonia with Acute Heart Failure

Figure 1 Patient enrolment and outcomes. 
Table 1 Baseline, demographic, clinical and laboratory characteristics for patients in four pneumonia groups

\begin{tabular}{|c|c|c|c|c|}
\hline Parameter & CAP $(n=137)$ & AP $(n=122)$ & HCAP $(n=74)$ & PAHF $(n=36)$ \\
\hline Males & $83(61)$ & $90(74)$ & $38(51)$ & $16(44)$ \\
\hline Age (years) & $80.5 \pm 10.9$ & $81.6 \pm 9$ & $83.8 \pm 7.9$ & $86.1 \pm 7.7$ \\
\hline Systolic blood pressure $(\mathrm{mm} \mathrm{Hg})$ & $125.6 \pm 28.8$ & $120.3 \pm 27.2$ & $109.7 \pm 25$ & $133.3 \pm 28.2$ \\
\hline Diastolic blood pressure $(\mathrm{mm} \mathrm{Hg})$ & $71.3 \pm 18.5$ & $70 \pm 16.7$ & $62.9 \pm 17.1$ & $73.4 \pm 21.2$ \\
\hline Heart rate (beats/min) & $96.9 \pm 25.4(n=136)$ & $95.5 \pm 24.1$ & $91 \pm 18.9$ & $87.9 \pm 18.9$ \\
\hline Body temperature $\left({ }^{\circ} \mathrm{C}\right)$ & $37.2 \pm 3.4(n=136)$ & $37.5 \pm 1.2$ & $37.1 \pm 1.1$ & $37.3 \pm 0.8$ \\
\hline Respiratory rate (bpm) & $26.7 \pm 6.6(n=26)$ & $\begin{array}{l}28.7 \pm 13.9 \\
(n=47)\end{array}$ & $\begin{array}{l}27.8 \pm 8.1 \\
(n=20)\end{array}$ & $\begin{array}{l}31.4 \pm 9.5 \\
(n=10)\end{array}$ \\
\hline Pulse oxymetory (\%) & $\begin{array}{l}90.3 \pm 9.9 \\
(n=136)\end{array}$ & $89.9 \pm 7.9$ & $88.1 \pm 10.3$ & $\begin{array}{l}89.6 \pm 8 \\
(n=35)\end{array}$ \\
\hline Leukocytes (cells $\times 10^{3} / \mu \mathrm{L}$ ) & $10.9 \pm 5.3$ & $10.6 \pm 5.3$ & $11.5 \pm 7.9$ & $8 \pm 3.4$ \\
\hline Haemoglobin (g/dL) & $12.1 \pm 1.9$ & $12.1 \pm 2.1$ & $11.5 \pm 1.9$ & $11 \pm 2.1$ \\
\hline Platelet count (cells $\left.\times 10^{10} / \mathrm{L}\right)$ & $24.2 \pm 17.2$ & $22.8 \pm 9.1$ & $22.4 \pm 10.2$ & $17.7 \pm 7.4$ \\
\hline Albumin (mg/dL) & $\begin{array}{l}2.91 \pm 0.62 \\
(n=116)\end{array}$ & $\begin{array}{l}2.93 \pm 0.59 \\
(n=113)\end{array}$ & $\begin{array}{l}2.64 \pm 0.5 \\
(n=67)\end{array}$ & $\begin{array}{l}2.92 \pm 0.6 \\
(n=28)\end{array}$ \\
\hline Alanine transaminase (IU/L) & $25.9 \pm 41.9$ & $24 \pm 27.7$ & $20.9 \pm 26.7$ & $19.9 \pm 13$ \\
\hline Creatinine $(\mathrm{mg} / \mathrm{dL})$ & $1.15 \pm 1.11$ & $0.95 \pm 0.62$ & $0.89 \pm 0.81$ & $1.17 \pm 1.19$ \\
\hline Plasma glucose (mg/dL) & $\begin{array}{l}141.5 \pm 63.9 \\
(n=133)\end{array}$ & $\begin{array}{l}150.6 \pm 79.7 \\
(n=120)\end{array}$ & $145 \pm 66.6$ & $\begin{array}{l}140.5 \pm 50.7 \\
(n=35)\end{array}$ \\
\hline $\mathrm{C}$ reactive protein $(\mathrm{mg} / \mathrm{dL})$ & $9.42 \pm 7.13$ & $6.88 \pm 5.61$ & $10.1 \pm 7.16$ & $6.78 \pm 6.58$ \\
\hline B-type natriuretic peptides ( $\mathrm{pg} / \mathrm{mL}$ ) & $176.2 \pm 239.4$ & $171.9 \pm 233.5$ & $267.3 \pm 552$ & $1020.3 \pm 1164.9$ \\
\hline $\mathrm{PaO}_{2}$ (Torr) & $\begin{array}{l}68 \pm 29.1 \\
(n=61)\end{array}$ & $\begin{array}{l}77.8 \pm 32.6 \\
(n=69)\end{array}$ & $\begin{array}{l}66.6 \pm 24.9 \\
(n=42)\end{array}$ & $\begin{array}{l}73.4 \pm 32.7 \\
(n=20)\end{array}$ \\
\hline $\mathrm{PaCO}_{2}$ (Torr) & $\begin{array}{l}37.8 \pm 10.2 \\
(n=61)\end{array}$ & $\begin{array}{l}38 \pm 7.6 \\
(n=69)\end{array}$ & $\begin{array}{l}40.7 \pm 11.8 \\
(n=42)\end{array}$ & $\begin{array}{l}34.7 \pm 10 \\
(n=20)\end{array}$ \\
\hline $\mathrm{PaO}_{2} / \mathrm{FiO}_{2}<200$ & $7 / 61(11)$ & $5 / 69(7)$ & $7 / 42(17)$ & $5 / 20(25)$ \\
\hline Metabolic acidosis & $8 / 61(13)$ & 6/69 (9) & $7 / 42(17)$ & $6 / 20(30)$ \\
\hline Bacteraemia & $3 / 46(7)$ & $2 / 42(5)$ & $2 / 31(6)$ & $1 / 6(17)$ \\
\hline Septic shock & $3(2)$ & $9(7)$ & $11(15)$ & $1(3)$ \\
\hline Disturbance of consciousness & $25(18)$ & $42(34)$ & $21(28)$ & $10(28)$ \\
\hline Pneumonia:>3 lobes of lung & $71(52)$ & $64(52)$ & $38(51)$ & $18(50)$ \\
\hline Malignancy & $9(7)$ & $3(2)$ & $5(7)$ & $3(8)$ \\
\hline Period of hospitalisation (days) & $21 \pm 15.2$ & $29.5 \pm 22.5$ & $22.5 \pm 19.6$ & $27.5 \pm 18.2$ \\
\hline Death within 30-day & $17(12)$ & $16(13)$ & $18(24)$ & $9(25)$ \\
\hline
\end{tabular}

Data are presented as mean $\pm \mathrm{SD}$ or $\mathrm{N}(\%)$ as appropriate.

$\mathrm{AP}$, aspiration pneumonia; CAP, community-acquired pneumonia; HCAP, healthcare-associated pneumonia; PAHF, pneumonia with acute heart failure.

Figure 2 A comparison of BNP levels for CAP and other types of pneumonia. BNP, B-type natriuretic peptides; CAP, community-acquired pneumonia.

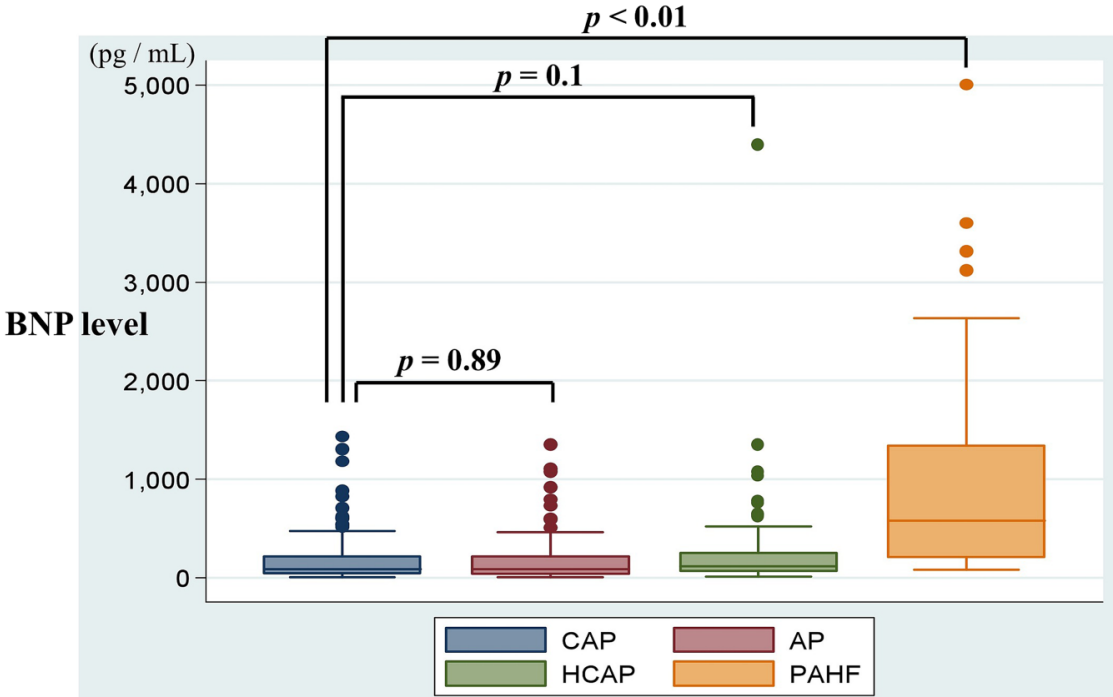

$\mathrm{BNP}=$ B-type natriuretic peptides, $\mathrm{CAP}=$ Community-Acquired Pneumonia, $\mathrm{AP}=$ Aspiration Pneumonia, $\mathrm{HCAP}=$ Healthcare-Associated Pneumonia, PAHF $=$ Pneumonia with Acute Heart Failure 


\section{RESULTS}

\section{Baseline characteristics}

A total of 673 patients were diagnosed with pneumonia during the period of this study. Of these, BNP levels were measured in the first $24 \mathrm{~h}$ of admission for a total of 369 patients, who were therefore included in the analysis. No statistical difference was found in the clinical and laboratory findings and in the frequency of pneumonia subgroups between the 304 excluded patients and 369 included patients. For the remaining 304 patients, 261 were excluded as BNP levels were not measured on admission and 43 were diagnosed with other types of pneumonia. Of the 369 patients included in the study, 137 were diagnosed with CAP, 122 with AP, 74 with HCAP and 36 with PAHF. The number of deaths was 17,
16,18 , and 9 , respectively, (mortality was $12 \%, 13 \%$, $24 \%$, and $25 \%$, respectively) (figure 1). Of $122 \mathrm{AP}$ patients, 6 were tested for swallowing disorders by otorhinolaryngologist, 60 were by speech-language-hearing therapist, 44 were by only nurse. On the other side, 12 were not tested because of their poor general conditions. Of 74 HCAP patients, 38 had also AP. Baseline, demographic, clinical and laboratory characteristics and outcome data were obtained for all patients (table 1). Compared CAP with other types of pneumonia for each variable, there were significant difference as follows: $\mathrm{C}$ reactive protein, disturbance of consciousness, period of hospitalisation in AP, systolic blood pressure, diastolic blood pressure, albumin, septic shock, 30-day mortality in HCAP, and heart rate, leucocytes, haemoglobin,

Table 2 Prediction of death in the univariate analysis: CAP

\begin{tabular}{|c|c|c|c|}
\hline Parameter & Survivors $(n=120)$ & Non-survivors $(n=17)$ & p Value \\
\hline Males & $72(60)$ & $11(65)$ & 0.71 \\
\hline Age (years) & $79.6 \pm 11.1$ & $86.2 \pm 7.1$ & 0.02 \\
\hline Systolic blood pressure $(\mathrm{mm} \mathrm{Hg})$ & $127.7 \pm 26.3$ & $110.8 \pm 40.3$ & 0.02 \\
\hline Diastolic blood pressure $(\mathrm{mm} \mathrm{Hg})$ & $72.5 \pm 17.4$ & $62.9 \pm 23.8$ & 0.04 \\
\hline Heart rate (beats/min) & $\begin{array}{l}97.1 \pm 23.4 \\
(n=119)\end{array}$ & $95 \pm 37.5$ & 0.75 \\
\hline Body temperature $\left({ }^{\circ} \mathrm{C}\right)$ & $37.5 \pm 1.1$ & $\begin{array}{l}34.4 \pm 9.2 \\
(n=16)\end{array}$ & 0.0003 \\
\hline Respiratory rate (breaths/min) & $\begin{array}{l}26.5 \pm 6.9 \\
(n=21)\end{array}$ & $\begin{array}{l}27.4 \pm 6.1 \\
(n=5)\end{array}$ & 0.79 \\
\hline Pulse oximetry (\%) & $\begin{array}{l}91.4 \pm 6.1 \\
(n=119)\end{array}$ & $82.7 \pm 22$ & 0.0006 \\
\hline 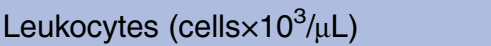 & $10.6 \pm 5.1$ & $12.9 \pm 6.4$ & 0.1 \\
\hline Haemoglobin (g/dL) & $12.3 \pm 1.8$ & $10.9 \pm 1.8$ & 0.003 \\
\hline Platelet count (cells $\left.\times 10^{10} / \mathrm{L}\right)$ & $25 \pm 17.9$ & $18.8 \pm 10.2$ & 0.17 \\
\hline Albumin (mg/dL) & $\begin{array}{l}2.96 \pm 0.58 \\
(n=99)\end{array}$ & $2.62 \pm 0.74$ & 0.04 \\
\hline Alanine transaminase (IU/L) & $23.6 \pm 30.7$ & $42.3 \pm 87.2$ & 0.08 \\
\hline Creatinine (mg/dL) & $1.05 \pm 0.95$ & $1.81 \pm 1.81$ & 0.008 \\
\hline Plasma glucose (mg/dL) & $\begin{array}{l}134.2 \pm 51 \\
(n=116)\end{array}$ & $191.1 \pm 109.6$ & 0.0005 \\
\hline $\mathrm{C}$ reactive protein (mg/dL) & $8.9 \pm 6.53$ & $13.15 \pm 9.95$ & 0.02 \\
\hline B-type natriuretic peptides $(\mathrm{pg} / \mathrm{mL})$ & $151.9 \pm 224.3$ & $347.7 \pm 278$ & $\begin{array}{l}0.001 \\
0.12\end{array}$ \\
\hline$\geqq 40$ & $89(74)$ & $16(94)$ & 0.007 \\
\hline$\geqq 100$ & 47 (39) & $13(76)$ & 0.002 \\
\hline$\geqq 200$ & $28(23)$ & $10(59)$ & \\
\hline $\mathrm{PaO}_{2}(\mathrm{~mm} \mathrm{Hg})$ & $\begin{array}{l}65.5 \pm 21.9 \\
(n=50)\end{array}$ & $\begin{array}{l}79.3 \pm 50.6 \\
(n=11)\end{array}$ & 0.16 \\
\hline $\mathrm{PaCO}_{2}(\mathrm{~mm} \mathrm{Hg})$ & $\begin{array}{l}37.7 \pm 9.2 \\
(n=50)\end{array}$ & $\begin{array}{l}38.4 \pm 14.3 \\
(n=11)\end{array}$ & 0.84 \\
\hline $\mathrm{PaO}_{2} / \mathrm{FiO}_{2}<200$ & $4 / 49(8)$ & $4 / 11(36)$ & 0.03 \\
\hline Metabolic acidosis & $4 / 50(8)$ & $4 / 11(36)$ & 0.03 \\
\hline Bacteraemia & $2 / 41(5)$ & $1 / 5(20)$ & 0.3 \\
\hline Septic shock & $0(0)$ & $3(18)$ & 0.002 \\
\hline Disturbance of consciousness & $17(14)$ & $8(47)$ & 0.001 \\
\hline Pneumonia: >3 lobes of lung & $62(52)$ & $9(53)$ & 0.92 \\
\hline Malignancy & $5(4)$ & $4(24)$ & 0.01 \\
\hline Period of hospitalisation (days) & $20.7 \pm 14.6$ & $23.4 \pm 19.3$ & 0.49 \\
\hline 30-day mortality & $12 \%$ & & \\
\hline
\end{tabular}


platelet count, C reactive protein, period of hospitalisation in PAHF. Missing data were confirmed for some parameters as the physicians at our hospital failed to confirm or measure them. BNP levels of all 369 populations were $275.4 \pm 538.6 \mathrm{pg} / \mathrm{mL}$. We compared BNP levels at admission between CAP and other types of pneumonia subgroups: AP, HCAP, or PAHF, and found they significantly lower than those for PAHF (BNP: $\quad 176.2 \pm 239.4 \mathrm{pg} / \mathrm{mL} \quad$ vs $1020.3 \pm 1164.9 \mathrm{pg} / \mathrm{mL}$, $\mathrm{p}<0.01$ ) (figure 2).

\section{Prediction of death in analysis}

In the univariate analysis, age, BNP (mean, cut-off points 100 and $200 \mathrm{pg} / \mathrm{mL}, \mathrm{p}<0.01$ respectively), metabolic acidosis, septic shock, disturbance of consciousness, malignancy, and $\mathrm{PaO}_{2} / \mathrm{FiO}_{2}<200$, along with measured levels of systolic blood pressure, diastolic blood pressure, body temperature, pulse oximetry, haemoglobin concentration, albumin, creatinine, plasma glucose and $\mathrm{C}$ reactive protein were associated with death in CAP (table 2). A similar situation was found for measured levels of haemoglobin concentration, BNP (cut-off points $200 \mathrm{pg} / \mathrm{mL}, \mathrm{p}<0.05$ ), $\mathrm{PaO}_{2} /$ $\mathrm{Fi}_{\mathrm{O} 2}<200$, disturbance of consciousness, in AP; $\mathrm{PaO}_{2} /$ $\mathrm{FiO}_{2}<200$, septic shock, disturbance of consciousness, malignancy, period of hospitalisation, and measured levels of body temperature, pulse oximetry in HCAP; and measured levels of diastolic blood pressure and albumin in PAHF (tables 3-5). In contrast, the BNP levels at admission were not predictive of mortality in the univariate analysis for HCAP or PAHF (tables 4 and 5). Therefore, we applied multivariable Cox-regression analysis only to CAP and AP. Here, in CAP, we added significant variables $(p<0.01)$ in univariate analysis to a multivariable model, because there were numerous ones. In multivariable Cox-regression analysis, BNP

Table 3 Prediction of death in the univariate analysis: AP

\begin{tabular}{|c|c|c|c|}
\hline Parameter & Survivors $(n=106)$ & Non-survivors $(n=16)$ & p Value \\
\hline Males & $77(73)$ & $13(81)$ & 0.56 \\
\hline Age (years) & $81.1 \pm 9.4$ & $84.8 \pm 5.1$ & 0.13 \\
\hline Systolic blood pressure $(\mathrm{mm} \mathrm{Hg})$ & $121.3 \pm 27.1$ & $113.3 \pm 28$ & 0.27 \\
\hline Diastolic blood pressure (mm Hg) & $70.2 \pm 16.7$ & $68.9 \pm 17$ & 0.78 \\
\hline Heart rate (beats/min) & $96.2 \pm 24.3$ & $91.2 \pm 23.3$ & 0.44 \\
\hline Body temperature $\left({ }^{\circ} \mathrm{C}\right)$ & $37.5 \pm 1.2$ & $37 \pm 0.9$ & 0.08 \\
\hline Respiratory rate (breaths/min) & $\begin{array}{l}29.4 \pm 14.5 \\
(n=39)\end{array}$ & $\begin{array}{l}25.4 \pm 10 \\
(n=8)\end{array}$ & 0.46 \\
\hline Pulse oximetry (\%) & $90.1 \pm 7.1$ & $88.5 \pm 12.3$ & 0.46 \\
\hline Leukocytes (cells $\left.\times 10^{3} / \mu \mathrm{L}\right)$ & $10.8 \pm 5.2$ & $8.7 \pm 5.5$ & 0.13 \\
\hline Haemoglobin (g/dL) & $12.3 \pm 2$ & $10.5 \pm 2.3$ & 0.001 \\
\hline Platelet count (cells $\left.\times 10^{10} / \mathrm{L}\right)$ & $22.9 \pm 9.3$ & $22.3 \pm 8.1$ & 0.8 \\
\hline Albumin $(\mathrm{mg} / \mathrm{dL})$ & $\begin{array}{l}2.93 \pm 0.58 \\
(n=98)\end{array}$ & $\begin{array}{l}2.93 \pm 0.65 \\
(n=15)\end{array}$ & 0.99 \\
\hline Alanine transaminase (IU/L) & $23.8 \pm 25.1$ & $25.5 \pm 42.3$ & 0.82 \\
\hline Creatinine (mg/dL) & $0.96 \pm 0.61$ & $0.89 \pm 0.67$ & 0.67 \\
\hline Plasma glucose (mg/dL) & $\begin{array}{l}154.3 \pm 82.7 \\
(n=104)\end{array}$ & $126.4 \pm 52.4$ & 0.19 \\
\hline $\mathrm{C}$ reactive protein $(\mathrm{mg} / \mathrm{dL})$ & $7.14 \pm 5.71$ & $5.19 \pm 4.69$ & 0.2 \\
\hline B-type natriuretic peptides ( $\mathrm{pg} / \mathrm{mL}$ ) & $172.1 \pm 246.2$ & $171.1 \pm 125.1$ & 0.99 \\
\hline$\geqq 40$ & $73(69)$ & $13(81)$ & 0.39 \\
\hline$\geqq 100$ & $43(41)$ & $10(63)$ & 0.1 \\
\hline 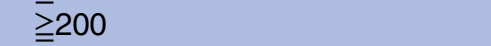 & $27(25)$ & $8(50)$ & 0.04 \\
\hline $\mathrm{PaO}_{2}(\mathrm{~mm} \mathrm{Hg})$ & $\begin{array}{l}79.3 \pm 33.1 \\
(n=58)\end{array}$ & $\begin{array}{l}69.9 \pm 30 \\
(n=11)\end{array}$ & 0.39 \\
\hline $\mathrm{PaCO}_{2}(\mathrm{~mm} \mathrm{Hg})$ & $\begin{array}{l}37.9 \pm 7.5 \\
(n=58)\end{array}$ & $\begin{array}{l}38.7 \pm 8.4 \\
(n=11)\end{array}$ & 0.73 \\
\hline $\mathrm{PaO}_{2} / \mathrm{FiO}_{2}<200$ & $3 / 57(5)$ & $3 / 11(27)$ & 0.04 \\
\hline Metabolic acidosis & 6/58 (10) & $0 / 11(0)$ & 0.58 \\
\hline Bacteraemia & $2 / 38(5)$ & $0 / 4(0)$ & 1 \\
\hline Septic shock & $7(7)$ & $2(13)$ & 0.34 \\
\hline Disturbance of consciousness & $33(31)$ & $9(56)$ & 0.04 \\
\hline Pneumonia: >3 lobes of lung & $54(51)$ & $10(63)$ & 0.39 \\
\hline Malignancy & $2(2)$ & $1(6)$ & 0.35 \\
\hline Period of hospitalisation (days) & $30.4 \pm 22.3$ & $23.7 \pm 23.8$ & 0.27 \\
\hline 30-day mortality & $13 \%$ & & \\
\hline
\end{tabular}


(cut-off points $200 \mathrm{pg} / \mathrm{mL}$ ), plasma glucose, and septic shock remained independent predictors of death in CAP (table 6). A similar situation was found for $\mathrm{PaO}_{2}$ / $\mathrm{FiO}_{2}<200$ in AP. Furthermore, for CAP, the area under the ROC curve (AUC) and likelihood ratios for different cut-off points are summarised (table 7). BNP level was accurate in predicting mortality $(\mathrm{AUC}=0.75)$. Its optimal cut-off point for predicting death was $224.1 \mathrm{pg} / \mathrm{mL}$, with a sensitivity of $58.8 \%$ and a specificity of $80.8 \%$. Its negative predictive cut-off value was $0.51 \%$, and the positive predictive cut-off value was $3.07 \%$.

\section{DISCUSSION}

In this cohort study of 369 patients presenting with CAP, AP, HCAP, and PAHF, the ability of plasma BNP levels at admission to predict unfavourable outcome for patients was determined. We report four major findings. First, a comparison of BNP levels at admission for CAP and
PAHF showed the former to be significantly lower than the latter. Second, BNP levels at admission are significantly elevated in decedents with CAP and AP. Third, a high BNP level $(\geq 200 \mathrm{pg} / \mathrm{mL})$ at admission is a predictor of CAP-related death. Fourth, BNP level was accurate in predicting mortality and its optimal cut-off point for predicting death was $224.1 \mathrm{pg} / \mathrm{mL}$. Given the high incidence of pneumonia and its prominent mortality rates, our findings are possibly of clinical importance.

The potential of BNP to predict CAP-related death observed in this study is in agreement with previous works. ${ }^{1521}$ Unfortunately, no direct comparison of BNP with CAP and AP, HACP, or PAHF, or validation of BNP as a prognostic marker in AP, HACP, or PAHF, was performed in these previous studies, therefore our results build on these findings. We would like to convey two our main messages to clinician from this paper. First, BNP can provide reliable data for timely to evaluate prognosis of CAP patients admitted to the hospital only by

Table 4 Prediction of death in the univariate analysis: HCAP

\begin{tabular}{|c|c|c|c|}
\hline Parameter & Survivors $(n=56)$ & Non-survivors $(n=18)$ & p Value \\
\hline Males & $27(48)$ & $11(61)$ & 0.34 \\
\hline Age (years) & $84.3 \pm 7.9$ & $82.1 \pm 7.9$ & 0.3 \\
\hline Systolic blood pressure (mm Hg) & $112.9 \pm 24.3$ & $99.9 \pm 24.9$ & 0.05 \\
\hline Diastolic blood pressure $(\mathrm{mm} \mathrm{Hg})$ & $64.9 \pm 15.4$ & $56.8 \pm 20.9$ & 0.08 \\
\hline Heart rate (beats/min) & $88.5 \pm 18.1$ & $98.5 \pm 19.7$ & 0.05 \\
\hline Body temperature $\left({ }^{\circ} \mathrm{C}\right)$ & $37.3 \pm 0.8$ & $36.5 \pm 1.6$ & 0.008 \\
\hline Respiratory rate (breaths/min) & $\begin{array}{l}26 \pm 7.4 \\
(n=10)\end{array}$ & $\begin{array}{l}29.5 \pm 8.8 \\
(n=10)\end{array}$ & 0.35 \\
\hline Pulse oximetry (\%) & $90.8 \pm 5$ & $79.5 \pm 16.5$ & 0.00 \\
\hline Leukocytes (cells $\times 10^{3} / \mu \mathrm{L}$ ) & $11.9 \pm 8.2$ & $10 \pm 6.9$ & 0.37 \\
\hline Haemoglobin $(\mathrm{g} / \mathrm{dL})$ & $11.5 \pm 1.9$ & $11.7 \pm 2.1$ & 0.7 \\
\hline Platelet count (cells $\left.\times 10^{10} / \mathrm{L}\right)$ & $22.6 \pm 9$ & $21.7 \pm 13.5$ & 0.76 \\
\hline Albumin (mg/dL) & $\begin{array}{l}2.69 \pm 0.48 \\
(n=55)\end{array}$ & $\begin{array}{l}2.43 \pm 0.55 \\
(n=12)\end{array}$ & 0.09 \\
\hline Alanine transaminase (IU/L) & $18.9 \pm 27.6$ & $27.1 \pm 23.1$ & 0.26 \\
\hline Creatinine $(\mathrm{mg} / \mathrm{dL})$ & $0.92 \pm 0.89$ & $0.78 \pm 0.52$ & 0.52 \\
\hline Plasma glucose (mg/dL) & $144.7 \pm 70.1$ & $146.1 \pm 55.8$ & 0.94 \\
\hline $\mathrm{C}$ reactive protein $(\mathrm{mg} / \mathrm{dL})$ & $9.93 \pm 7.18$ & $10.78 \pm 7.28$ & 0.67 \\
\hline B-type natriuretic peptides ( $\mathrm{pg} / \mathrm{mL})$ & $228.6 \pm 287.4$ & $387.8 \pm 1030.3$ & 0.29 \\
\hline$\geqq 40$ & $47(84)$ & $16(89)$ & 1 \\
\hline$\geqq 100$ & $30(54)$ & $10(56)$ & 0.88 \\
\hline$\geqq 200$ & $20(36)$ & $6(33)$ & 0.85 \\
\hline $\mathrm{PaO}_{2}(\mathrm{~mm} \mathrm{Hg})$ & $\begin{array}{l}63.7 \pm 18 \\
(n=28)\end{array}$ & $\begin{array}{l}72.5 \pm 34.3 \\
(n=14)\end{array}$ & 0.28 \\
\hline $\mathrm{PaCO}_{2}(\mathrm{~mm} \mathrm{Hg})$ & $\begin{array}{l}39.3 \pm 11.9 \\
(n=28)\end{array}$ & $\begin{array}{l}43.7 \pm 11.3 \\
(n=14)\end{array}$ & 0.25 \\
\hline $\mathrm{PaO}_{2} / \mathrm{FiO}_{2}<200$ & $2 / 27(7)$ & $5 / 14(36)$ & 0.04 \\
\hline Metabolic acidosis & $3 / 25(11)$ & 4/14 (29) & 0.2 \\
\hline Bacteraemia & $1 / 22(5)$ & $1 / 9(11)$ & 0.5 \\
\hline Septic shock & $4(7)$ & $7(39)$ & 0.003 \\
\hline Disturbance of consciousness & $11(20)$ & $10(56)$ & 0.003 \\
\hline Pneumonia: >3 lobes of lung & $26(46)$ & $12(67)$ & 0.14 \\
\hline Malignancy & $0(0)$ & $5(28)$ & 0.001 \\
\hline Period of hospitalisation (days) & $26.4 \pm 20.6$ & $10.4 \pm 9.1$ & 0.002 \\
\hline 30-day mortality & $24 \%$ & & \\
\hline
\end{tabular}

Data are presented as mean \pm SD for continuous variables, and count (\%) for categorical variables. HCAP, healthcare-associated pneumonia. 
Table 5 Prediction of death in the univariate analysis: PAHF

\begin{tabular}{|c|c|c|c|}
\hline Parameter & Survivors $(n=27)$ & Non-survivors $(n=9)$ & p Value \\
\hline Males & $13(48)$ & $3(33)$ & 0.7 \\
\hline Age (years) & $85.4 \pm 8.4$ & $88.2 \pm 5.2$ & 0.36 \\
\hline Systolic blood pressure $(\mathrm{mm} \mathrm{Hg})$ & $137.4 \pm 29.8$ & $121 \pm 19.1$ & 0.13 \\
\hline Diastolic blood pressure $(\mathrm{mm} \mathrm{Hg})$ & $78.4 \pm 20.8$ & $58.2 \pm 15$ & 0.01 \\
\hline Heart rate (beats/min) & $87.6 \pm 19.5$ & $88.8 \pm 18$ & 0.87 \\
\hline Body temperature $\left({ }^{\circ} \mathrm{C}\right)$ & $37.2 \pm 0.9$ & $37.4 \pm 0.7$ & 0.5 \\
\hline Respiratory rate (breaths/min) & $\begin{array}{l}30.7 \pm 9.8 \\
(n=9)\end{array}$ & $\begin{array}{l}38 \\
(n=1)\end{array}$ & - \\
\hline Pulse oximetry (\%) & $\begin{array}{l}90.1 \pm 8.9 \\
(n=26)\end{array}$ & $88.2 \pm 4.7$ & 0.55 \\
\hline Leukocytes (cells $\times 10^{3} / \mu \mathrm{L}$ ) & $7.7 \pm 2.8$ & $9.2 \pm 5$ & 0.25 \\
\hline Haemoglobin $(g / d L)$ & $11.3 \pm 2.2$ & $10.2 \pm 1.6$ & 0.16 \\
\hline Platelet count (cells $\left.\times 10^{10} / \mathrm{L}\right)$ & $17.7 \pm 7.8$ & $17.6 \pm 6.7$ & 0.96 \\
\hline Albumin (mg/dL) & $\begin{array}{l}3.11 \pm 0.49 \\
(n=20)\end{array}$ & $\begin{array}{l}2.46 \pm 0.65 \\
(n=8)\end{array}$ & 0.008 \\
\hline Alanine transaminase (IU/L) & $19.8 \pm 13.8$ & $20.1 \pm 10.6$ & 0.95 \\
\hline Creatinine $(\mathrm{mg} / \mathrm{dL})$ & $1.26 \pm 1.32$ & $0.91 \pm 0.64$ & 0.45 \\
\hline Plasma glucose (mg/dL) & $\begin{array}{l}146.7 \pm 46.9 \\
(n=26)\end{array}$ & $122.4 \pm 59.7$ & 0.22 \\
\hline$C$ reactive protein $(\mathrm{mg} / \mathrm{dL})$ & $6.52 \pm 7.35$ & $7.53 \pm 3.63$ & 0.7 \\
\hline B-type natriuretic peptides $(\mathrm{pg} / \mathrm{mL})$ & $849.8 \pm 880.3$ & $1531.7 \pm 1739.6$ & 0.13 \\
\hline$\geqq 40$ & $27(100)$ & $9(100)$ & - \\
\hline$\geqq 100$ & $25(93)$ & $9(100)$ & 1 \\
\hline 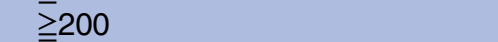 & $22(81)$ & $6(67)$ & 0.38 \\
\hline $\mathrm{PaO}_{2}(\mathrm{~mm} \mathrm{Hg})$ & $\begin{array}{l}79.5 \pm 35.7 \\
(n=15)\end{array}$ & $\begin{array}{l}55.1 \pm 7 \\
(n=5)\end{array}$ & 0.15 \\
\hline $\mathrm{PaCO}_{2}(\mathrm{~mm} \mathrm{Hg})$ & $\begin{array}{l}34 \pm 9.9 \\
(n=15)\end{array}$ & $\begin{array}{l}36.7 \pm 11.2 \\
(n=5)\end{array}$ & 0.61 \\
\hline $\mathrm{PaO}_{2} / \mathrm{FiO}_{2}<200$ & $4 / 15(27)$ & $1 / 4(25)$ & 1 \\
\hline Metabolic acidosis & $4 / 15(27)$ & $2 / 5(40)$ & 0.61 \\
\hline Bacteraemia & $0 / 5(0)$ & $1 / 1(100)$ & 0.17 \\
\hline Septic shock & $1(4)$ & $0(0)$ & 1 \\
\hline Disturbance of consciousness & $7(26)$ & $3(33)$ & 0.69 \\
\hline Pneumonia: $>3$ lobes of lung & $13(48)$ & $5(56)$ & 1 \\
\hline Malignancy & $2(7)$ & $1(13)$ & 1 \\
\hline Period of hospitalisation (days) & $26 \pm 15.5$ & $31.8 \pm 25.4$ & 0.42 \\
\hline 30-day mortality & $25 \%$ & & \\
\hline
\end{tabular}

Data are presented as mean \pm SD for continuous variables, and count (\%) for categorical variables. PAHF, pneumonia with acute heart failure.

measuring its level, hence clinicians can conduct proper empiric therapy on admission. The major limitation for the routine use of the PSI, CURB-65, and A-DROP scoring system is its laborious calculation. According to a growing body of evidence, a simple BNP level provides equivalent prognostic information as the complex variable severity index. Second, BNP had been regarded as a marker for heart failure, however it also could play a new role as a prognostic marker for pneumonia.

The pathophysiologic mechanism for oversecretion of BNP is not completely understood. ${ }^{5}$ In general, BNP is an acute-phase reactant and plays an important role in regulating body fluid volume, vascular pressure and electrolyte balance. ${ }^{15}{ }^{21-24}$ And secretion of BNP is suggested to be triggered by hypoxia, leading to pulmonary vasoconstriction, pulmonary hypertension and right heart overload. ${ }^{1}$ On the other hand, since BNP levels are significantly increased in patients with severe sepsis and septic shock, the plasma concentration of BNP can be used as a reliable indicator for identification of sepsis-induced myocardial inhibition. ${ }^{5} 2124$ Additionally, the activation of proinflammatory cytokine and the sympathetic nervous system has also been identified as an inducing factor of BNP secretion. ${ }^{121}$ Consequently, BNP may mirrors inflammatory response as well as the presence of disease-relevant co-morbidities and hypoxia. ${ }^{1}$ CAP is a significant stressor to the cardiovascular system through low peripheral vascular resistance, increased cardiac output, and the occurrence of arteriovenous shunts in inflamed areas. ${ }^{5}$ On the other hand, patients with CAP usually suffer from partial hypoxia in the pulmonary vascular system. ${ }^{1}$ Based on these findings, BNP levels in patients with CAP are suggested to integrate the degree of acute cardiac stress, the extent of systemic inflammation, and the presence of relevant comorbidities, especially chronic cardiac disease. ${ }^{5}$ Therefore, 
Table 6 Prediction of death in the multivariable cox-regression analysis: CAP and AP

\begin{tabular}{|c|c|c|c|c|}
\hline Type of pneumonia & Parameter & HR & $95 \% \mathrm{Cl}$ & p Value \\
\hline \multirow[t]{9}{*}{ CAP } & BNP $(\geqq 200 \mathrm{pg} / \mathrm{mL})$ & 10.01 & 1.32 to 75.7 & 0.03 \\
\hline & $\mathrm{BNP}(\geqq 100 \mathrm{pg} / \mathrm{mL})$ & 0.36 & 0.04 to 3.21 & 0.36 \\
\hline & Body temperature $\left(>38^{\circ} \mathrm{C}\right.$ or $\left.\leqq 36^{\circ} \mathrm{C}\right)$ & 0.26 & 0.05 to 1.3 & 0.1 \\
\hline & Pulse oximetry $(<90 \%)$ & 1.66 & 0.47 to 5.8 & 0.43 \\
\hline & Haemoglobin (>17.4 g/dL or $<13.7 \mathrm{~g} / \mathrm{dL})$ & 1.41 & 0.15 to 13.3 & 0.76 \\
\hline & Creatinine $(>1.1 \mathrm{mg} / \mathrm{dL}$ or $<0.6 \mathrm{mg} / \mathrm{dL})$ & 1.76 & 0.47 to 6.58 & 0.4 \\
\hline & Plasma glucose (>109 mg/dL or $<70 \mathrm{mg} / \mathrm{dL}$ ) & 7.15 & 1.28 to 40.1 & 0.03 \\
\hline & Septic shock & 94.4 & 9.22 to 967.2 & $<0.001$ \\
\hline & Disturbance of consciousness & 2.87 & 0.88 to 9.39 & 0.08 \\
\hline \multirow[t]{4}{*}{ AP } & $\mathrm{BNP}(\geqq 200 \mathrm{pg} / \mathrm{mL})$ & 3.44 & 0.95 to 12.4 & 0.06 \\
\hline & Haemoglobin $(>17.4 \mathrm{~g} / \mathrm{dL}$ or $<13.7 \mathrm{~g} / \mathrm{dL})$ & 2.59 & 0.3 to 22.7 & 0.39 \\
\hline & $\mathrm{PaO}_{2} / \mathrm{FiO}_{2}<200$ & 7.35 & 1.74 to 31 & 0.007 \\
\hline & Disturbance of consciousness & 2.35 & 0.58 to 9.53 & 0.23 \\
\hline
\end{tabular}

elevated BNP levels in patients with CAP and known concomitant heart failure might at least partially explain the predictive potential of BNP. ${ }^{1}$ On the other hand, according to our knowledge, we could not find paper mentioned to the mechanism for elevation in patients with AP, HCAP, nor PAHF.

Several limitations merit consideration. First, we conducted a single centre study. Second, we cannot comment on the potential of BNP measurements in patients who were excluded from the analysis. Third, we failed to measure BNP for all pneumonia patients, hence selection bias cannot be completely excluded. Fourth, we should have measured the serum BNP levels in the convalescent phase in addition to the acute phase for evaluation as a decrease in these levels post-treatment, which is compatible with control subjects, would show that BNP levels were transiently elevated in patients with pneumonia. Fifth, physicians at our hospital failed to confirm respiratory rates for a number of patients on admission. Consequently, we were unable to compare the validity of BNP and PSI, CURB-65, a clinical prediction rule that has been validated for predicting mortality in CAP and infection at any site and is recommended by the British Thoracic Society for assessment of the severity of pneumonia. ${ }^{25}$ Sixth, compared CAP with other types of

Table 7 BNP thresholds to predict mortality.

\begin{tabular}{lllll}
\hline $\begin{array}{l}\text { Cut-off } \\
\text { BNP (pg/ } \\
\text { mL) }\end{array}$ & $\begin{array}{l}\text { Sensitivity } \\
\text { (\%) }\end{array}$ & $\begin{array}{l}\text { Specificity } \\
\text { (\%) }\end{array}$ & $\begin{array}{l}\text { LR+ } \\
(\%)\end{array}$ & $\begin{array}{l}\text { LR- } \\
\text { (\%) }\end{array}$ \\
\hline 100 & 76.5 & 60.8 & 1.95 & 0.39 \\
200 & 58.8 & 75.8 & 2.43 & 0.54 \\
$224.1^{*}$ & 58.8 & 80.8 & 3.07 & 0.51 \\
300 & 47.1 & 87.5 & 3.76 & 0.61 \\
\hline
\end{tabular}

BNP, B-type natriuretic peptide; LR+, positive likelihood ratio; LR-, negative likelihood ratio.

*The best calculated cut-off.

Sensitivity, specificity, positive likelihood ratio, negative likelihood ratio at different cut-off levels. pneumonia for baseline, demographic, clinical, and laboratory characteristics and outcome data, there were significant difference in some variables.

\section{CONCLUSIONS}

BNP levels may be a useful single prognostic marker for CAP. On the other hand, we will continue to collect more samples in the future to establish new acknowledgement. In this regard, further studies are required to validate their utility with other types of pneumonia and to assess their application in clinical practice.

Acknowledgements The authors thank Mizuno T, Atsumi H, Ishigami $\mathrm{K}$, Okamura H, Kiyosawa J, Saito A, Asano M, Iguchi M, Urashima S, and Fukuda A for much assistance in all aspects of data collection.

Contributors DU, YI and TK were involved concept and design; DU, RS, YH, EM, YI and TK acquisition of data, approval of manuscript; DU, YH, EM and TK analysis/interpretation of data.

Funding This research received no specific grant from any funding agency in the public, commercial or not-for-profit sectors.

Competing interests The authors have reported to BMJ Open that no potential conflicts of interest exist with any companies/organisations whose products or services may be discussed in this article. And the sponsor had no role in the design of the study, the collection and analysis of the data, or the preparation of the manuscript.

Patient consent Obtained.

Ethics approval The ethics committee at Kanazawa Medical University Himi Municipal Hospital (approval number 48).

Provenance and peer review Not commissioned; externally peer reviewed.

Data sharing statement No additional data are available.

Open Access This is an Open Access article distributed in accordance with the Creative Commons Attribution Non Commercial (CC BY-NC 4.0) license, which permits others to distribute, remix, adapt, build upon this work noncommercially, and license their derivative works on different terms, provided the original work is properly cited and the use is non-commercial. See: http:// creativecommons.org/licenses/by-nc/4.0/

\section{REFERENCES}

1. Christ-Crain M, Breidthardt T, Stolz D, et al. Use of B-type natriuretic peptide in the risk stratification of community-acquired pneumonia. $\mathrm{J}$ Intern Med 2008;264:166-76. 
2. Janssens JP, Krause KH. Pneumonia in the very old. Lancet Infect Dis 2004;4:112-24.

3. Statistical database managed by the Statistics and Information Department, Ministry of Health, Labour and Welfare, Japan. 2013. http://www.mhlw.go.jp/toukei/saikin/hw/jinkou/kakutei14/dl/10_h6.pdf

4. Kohno S, Seki M, Watanabe A, et al. Evaluation of an assessment system for the JRS 2005: a-DROP for the management of CAP in adults. Intern Med 2011;50:1183-91.

5. Nowak A, Breidthardt T, Christ-Crain M, et al. Direct comparison of three natriuretic peptides for prediction of short- and long-term mortality in patients with community-acquired pneumonia. Chest 2012;141:974-82.

6. Menéndez R, Martínez R, Reyes S, et al. Biomarkers improve mortality prediction by prognostic scales in community-acquired pneumonia. Thorax 2009;64:587-91.

7. Wang LJ, Mu SC, Lin CH, et al. Fatal community-acquired pneumonia: 18 years in a medical center. Pediatr Neonatol 2013;54:22-7.

8. Riquelme R, Torres A, El-Ebiary M, et al. Community-acquired pneumonia in the elderly: a multivariate analysis of risk and prognostic factors. Am J Respir Crit Care Med 1996;154: 1450-5.

9. Molinos L, Clemente MG, Miranda B, et al. Community-acquired pneumonia in patients with and without chronic obstructive pulmonary disease. J Infect 2009;58:417-24.

10. Kothe $\mathrm{H}$, Bauer $\mathrm{T}$, Marre $\mathrm{R}$, et al. Outcome of community-acquired pneumonia: influence of age, residence status and antimicrobial treatment. Eur Respir J 2008;32:139-46.

11. Falguera M, Pifarre R, Martin A, et al. Etiology and outcome of community-acquired pneumonia in patients with diabetes mellitus. Chest 2005;128:3233-9.

12. Clemente MG, Budiño TG, Seco GA, et al. Community-acquired pneumonia in the elderly: prognostic factors. Arch Bronconeumol 2002;38:67-71.

13. Melzer M, Welch C. 30-day mortality in UK patients with bacteraemic community-acquired pneumonia. Infection 2013;41:1005-11.

14. Cheng V, Kazanagra R, Garcia A, et al. A rapid bedside test for B-type peptide predicts treatment outcomes in patients admitted for decompensated heart failure: a pilot study. J Am Coll Cardiol 2001;37:386-91.
15. Cabanes L, Richaud-Thiriez B, Fulla Y, et al. Brain natriuretic peptide blood levels in the differential diagnosis of dyspnea. Chest 2001;120:2047-50.

16. Komiya $\mathrm{K}$, Ishii $\mathrm{H}$, Umeki $\mathrm{K}$, et al. Impact of aspiration pneumonia in patients with community-acquired pneumonia and healthcareassociated pneumonia: a multicenter retrospective cohort study. Respirology 2013;18:514-21.

17. Committee for the Japanese Respiratory Society Guidelines in Management of Respiratory. Aspiration pneumonia. Respirology 2004:9(Suppl 1):S35-7.

18. The committee for the Japanese Respiratory Society guidelines for the management of nursing and healthcare-associated pneumonia. The Japanese Respiratory Society guidelines for the management of nursing and healthcare-associated pneumonia. Tokyo: The Japanese Respiratory Society, 2011.

19. An JD, Zhang YP, Zhou JH. Levels of serum brain natriuretic peptide in children with congestive heart failure or with severe pneumonia. Zhongguo Dang Dai Er Ke Za Zhi 2006;8:201-4.

20. González-González Al, Lobos-Bejarano J, Horrillo-García C, et al. Brain natriuretic peptide in primary care: diagnostic value in heart failure. Aten Primaria 2005;36:510-14.

21. Li J, Ye H, Zhao L. B-type natriuretic peptide in predicting the severity of community-acquired pneumonia. World J Emerg Med 2015;6:131-6.

22. Yetkin O, Hacievliyagil SS, Gunen H. Assessment of B-type natriuretic peptide in patients with pneumonia. Int $\mathrm{J}$ Clin Pract 2008;62:488-91.

23. Scali MC, Simioniuc A, Dini FL, et al. The potential value of integrated natriuretic peptide and echo-guided heart failure management. Cardiovasc Ultrasound 2014;12:27.

24. Leli C. Utility of brain natriuretic peptide as prognostic marker in community-acquired pneumonia and chronic obstructive pulmonary disease exacerbation patients presenting to the emergency department. Infez Med 2011;19:235-40.

25. Fine MJ, Auble TE, Yealy DM, et al. A prediction rule to identify low-risk patients with community-acquired pneumonia. $N$ Engl J Med 1997;336:243-50.

26. British Thoracic Society Standards of Care Committee. BTS guidelines for the management of community acquired pneumonia in adults. Thorax 2001;56(Suppl 4):IV1-64. 